\title{
The Selective Expression of Ret Finger Protein in Endometrial Cancer: Can RFP be a Marker of Serous Carcinomas?
}

\section{Ret Finger Proteininin Endometrium Kanserlerinde Seçici Ekspresyonu: RFP Seröz Kanserlerin Belirteci Olarak Kullanılabilir mi?}

\author{
Gaye Güler TEZEL, Zehra ORDULU, Çiğdem HIMMETOĞLU, Alp USUBÜTÜN \\ Department of Pathology, Hacettepe University, Faculty of Medicine, ANKARA, TURKEY
}

\begin{abstract}
Objective: Endometrial cancer is a common malignancy of the gynecological system and has been classified into two major groups, Types I and II. Type I tumors are estrogen-related, low-grade endometrioid tumors, whereas type II tumors are aggressive, high-grade non-endometrioid tumors. Ret finger protein is a nuclear transcription factor with a tripartite motif that is highly expressed in different tumor cells.
\end{abstract}

Material and Method: To analyze the expression of ret finger protein in endometrial tissues and cancer, 18 cases of secretory and proliferative endometrium, endometrial polyp, endometrial hyperplasia and endometrial intraepithelial neoplasia and 21 cases of types I and II endometrial carcinoma were evaluated immunohistochemically.

Results: Although rare cases of secretory endometrium showed a weak focal nuclear positivity, remaining proliferative endometrium, endometrial hyperplasia and type I endometrioid cancer cases were negative. In contrast, all cases of serous cancers showed strong nuclear positivity. After these strong positive results for serous endometrial cancer, 12 more cases of ovarian and endometrial serous carcinoma cases were added to the study. All of the additional cases were also strongly positive for ret finger protein.

Conclusion: We suggest that ret finger protein might play a role in the carcinogenesis of the serous tumors of gynecological system and can be used to differentiate serous carcinomas from other epithelial tumors.

Key Words: Endometrial cancer, Serous carcinoma, Ret finger protein

(Turk Patoloji Derg 2012, 28:213-219)

Received : 05.03.2012 Accepted : 18.05.2012
ÖZ

Amaç: Endometrium kanseri, kadın genital sisteminin en sık görülen kanserlerinden biri olup, tip I ve tip II olmak üzere iki ana grupta sınıflandırılmaktadır. Tip I tümörler genellikle östrojen hormonu ile bağlantılı olup, düşük dereceli, endometrioid morfolojiye sahipken; tip II tümörler genellikle agresif davranışlı ve yüksek dereceli, endometrioid dışı morfoloji sergilemektedir. Ret finger protein üç parçalı motif yapısında nükleer bir transkripsiyon faktörü olup birçok tümörde yüksek miktarda eksprese edilmektedir.

Gereç ve Yöntem: Tip I ve II endometrial karsinom örnekleri (toplam 21 adet) ile sekretuvar endometrium, endometrial polip, endometrial hiperplazi ve endometrial intraepitelial neoplazi tanısı almış dokular (toplam 18 adet) immünohistokimyasal teknikle boyanarak ret finger protein ekspresyonu açısından karşılaştırmalı olarak değerlendirildi.

Bulgular: Sekretuvar endometriumda çok nadir olarak zayıf nükleer ekspresyon saptanırken, tüm proliferatif endometrium, endometrial hiperplazi ve tip I endometrium karsinom olgular1 ret finger protein ile negatif boyanma gösterdi. Buna karşın, tüm endometrial seröz karsinom dokuları ile daha sonra ek olarak boyanan 12 adet over ve endometrial seröz karsinom örneğinin ret finger protein ile kuvvetli pozitif nükleer ekspresyon gösterdiği saptandı.

Sonuç: Ret finger proteininin over ve endometrial seröz karsinomlardaki seçici ekspresyonu, hem bu proteinin seröz karsinomların patogenezindeki rolünün ortaya çıkarılmasında hem de seröz tümörlerin kadın genital sisteminde gelişen diğer epitelyal tümörlerden ayrılmasında faydalı olabilir.

Anahtar Sözcükler: Endometrial neoplazi, Seröz adenokarsinom, Ret finger protein
Correspondence: Çiğdem HIMMETOĞLU

Department of Pathology, Hacettepe University, Faculty of Medicine, ANKARA, TURKEY

E-mail: cigdem.himmetoglu@gmail.com Phone: +90 5334906369 


\section{INTRODUCTION}

Endometrial cancer is one of the common malignancies of the female genital tract. This cancer is the seventh most common cancer of women worldwide and has the highest incidence in Western countries (1). Almost $90 \%$ of endometrial cancers are sporadic, whereas the remaining $10 \%$ of cases are hereditary (2). Based on the etiology, clinical behavior and pathological characteristics, a dualistic model of endometrial tumorigenesis has long been recognized and broadly termed as types I and II (3).

Type I endometrial cancers are histologically low-grade endometrioid carcinomas with a favorable prognosis and represent about $70-80 \%$ of sporadic endometrial carcinomas. These tumors are associated with unopposed estrogen exposure and usually develop in perimenopausal women, with the risk factors of obesity, anovulation, nulliparity, and exogenous estrogen exposure. They arise in a background of complex and atypical endometrial hyperplasia and commonly express estrogen and progesterone receptors (ER and PR). Although they are rare, mucinous adenocarcinomas are also considered within this group since they have low histopathological grade and usually express ER and PR $(3,4)$.

On the other hand, type II cancers are histologically highgrade non-endometrioid carcinomas, most frequently serous papillary, have an aggressive clinical behavior and represent about $10-20 \%$ of endometrial cancers. These tumors are unrelated to estrogen excess, and usually develop in older postmenopausal women, without any hormonal risk factors. They arise in a background of atrophic endometrium with the putative precursor lesion being endometrial intraepithelial carcinoma and occasionally endometrial polyps. Although the histological prototype for type II tumors is serous carcinomas, the less frequent clear cell carcinoma is also considered within this group (3, 4).

Ret finger protein (RFP) is a nuclear protein that belongs to B-box RING finger family and consists of a tripartite motif including RING finger, B-box zinc finger and coiled coil domain (5-8). The interest in RFP was originally arose from its oncogenic activity when fused with the RET tyrosine kinase (9). RFP mRNA is highly expressed in various human and rodent tumor cell lines (10). RFP expression is detected in male germ cells, peripheral and central neurons, hepatocytes, adrenal chromaffin cells, as well as breast cancer and seminomas (11-13). Although RFP is highly expressed in different tumor types, the exact function of RFP in cancer remains unclear.
To our knowledge, there are only two studies related with the expression of RFP in endometrial cancer in the literature. Zhang et al. investigated the levels of RFP expression among cervical squamous cell carcinomas, endometrial adenocarcinomas, normal cervix and endometrium (14). Tsukamoto et al. examined the clinical significance of RFP expression in endometrial cancer (15). However, neither of these two studies compared RFP expression in endometrial cancer with respect to morphological characteristics.

Herein, the expression of RFP in benign, hyperplastic and neoplastic endometrium, as well as type I and type II endometrial cancer cases was analyzed to understand its morphological selectivity.

\section{MATERIAL and METHOD}

Tissue samples: The paraffin blocks of randomly chosen cases included in this study were selected from the archives of the pathology department. Two pathologists (GGT and $\mathrm{AU})$ re-evaluated the morphologic features. Of the 39 cases, 18 cases were benign ( 3 cases with secretory endometrium, 2 cases with proliferative endometrium, 5 endometrial polyp, 3 benign endometrial hyperplasia and 5 endometrial intraepithelial neoplasia [EIN]); and 21 cases were type I (16 endometrioid cases including high grade tumors) and type II ( 3 serous, 2 clear cell) endometrial carcinoma. After the strong positive results selectively for serous endometrial cancer cases, 12 more cases of ovarian ( 9 cases) and endometrial serous ( 3 cases) carcinoma were added to the study to analyze organ and/or morphology specificity.

Immunohistochemistry: Four micron sections obtained from the selected cases were stained for RFP. Immunohistochemical staining was carried out by the strepto-avidin biotin method, using a commercially available kit (UltraTek HRP Anti-Polyvalent Lab Pack, ScyTek Laboratories). Anti-RFP antibody (12) was used as a primary antibody. Briefly, deparaffinized sections were treated with methanol containing $0.3 \% \mathrm{H}_{2} \mathrm{O}_{2}$ for $15 \mathrm{~min}$ for endogenous peroxide blockage. After washing with PBS, blocking solution was applied for $5 \mathrm{~min}$. All slides received pretreatment with citrate for antigen retrieval. Then, RFP primary antibody was allowed to react at room temperature for $60 \mathrm{~min}$ in dilution of 1:750. After washing in PBS, secondary antibody was applied for $10 \mathrm{~min}$, followed by horseradish peroxidase-marked strepto-avidin for $10 \mathrm{~min}$. Peroxidase was visualized by diaminobenzidine tetrahydrochloride containing $0.3 \% \mathrm{H}_{2} \mathrm{O}_{2}$. Nuclei were stained with Harris' hematoxylin. Appropriate controls were included for this study. The RFP expression was evaluated as positive when there was nuclear staining in more than $5 \%$ of nuclei. 


\section{RESULTS}

RFP expression was negative in 18 benign cases (secretory endometrium [ 1 cases], proliferative endometrium [2 cases], endometrial polyp [5 cases), benign endometrial hyperplasia [3 cases] and EIN [5 cases]) except for 2 secretory endometrium cases showing weak focal nuclear positivity (Figure 1). Among 21 cases of endometrial carcinoma, all type I cases were negative (Figure 2). Interestingly all of the serous carcinoma cases ( 3 cases) showed diffuse strong nuclear positivity (Figure 3). Of

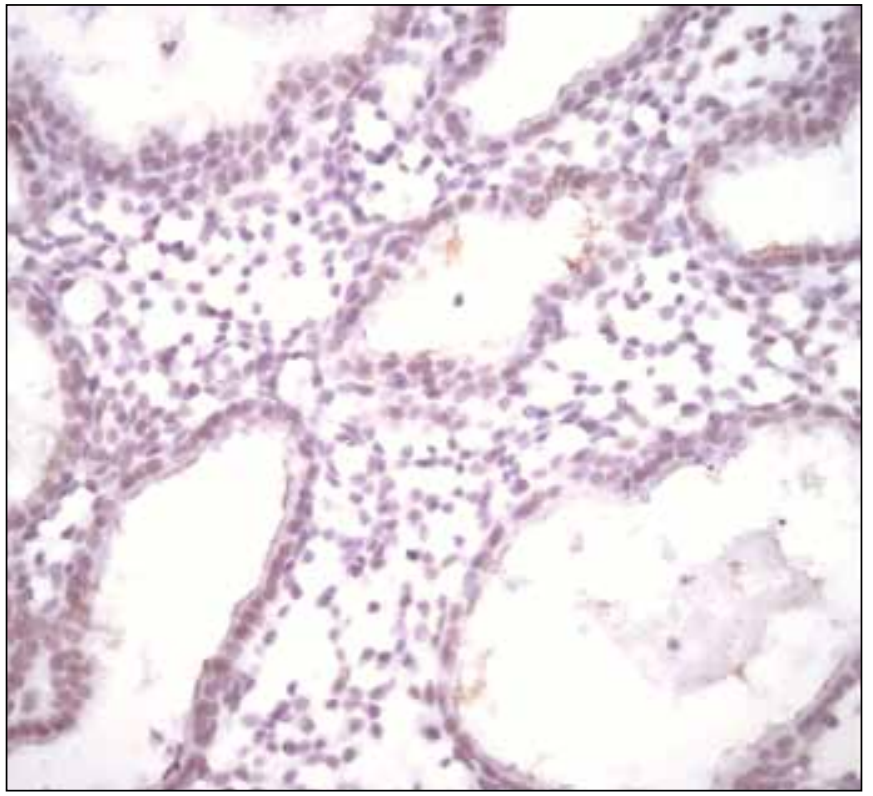

Figure 1: Immunohistochemical staining for RFP expression in secretory endometrium (x200).

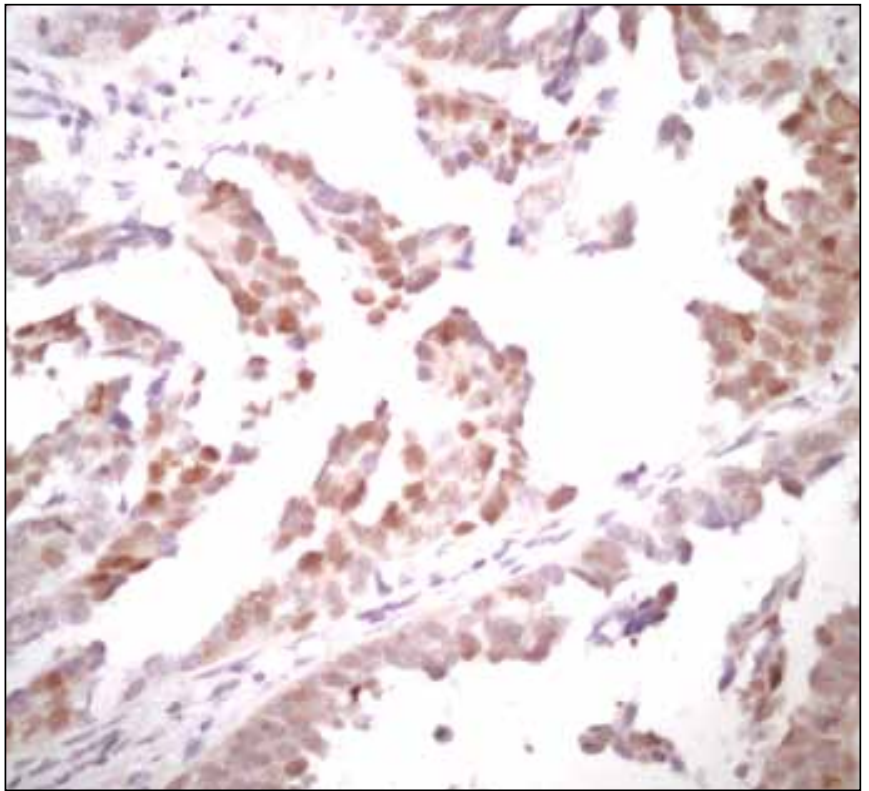

Figure 3: Immunohistochemical staining for RFP expression in endometrial serous carcinoma (x200). note, one of the two endometrial clear cell carcinoma cases showed intermediate nuclear positivity.

After the strong nuclear positive results for only endometrial serous adenocarcinoma cases, 12 cases including 9 ovarian and 3 endometrial serous carcinoma cases were added to the study to analyze tissue and/or morphology specificity. All of these additional 12 cases; including 9 ovarian and 3 endometrial serous carcinoma cases were also showed strong and diffuse positivity for nuclear RFP expression (Figure 4).

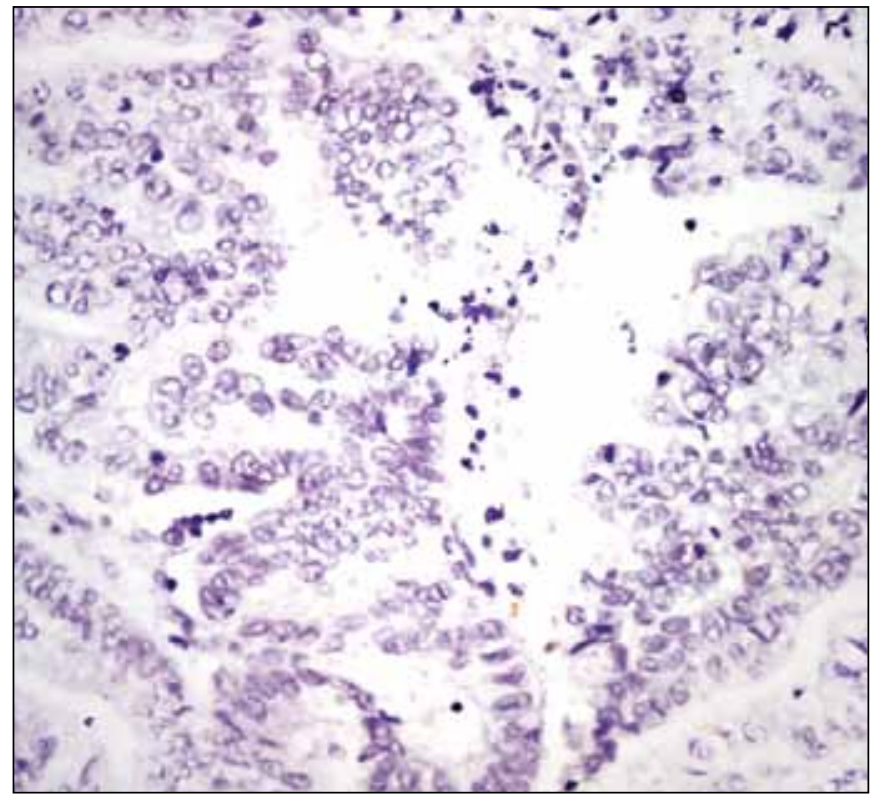

Figure 2: Immunohistochemical staining for RFP expression in endometrioid type endometrial carcinoma (x200).

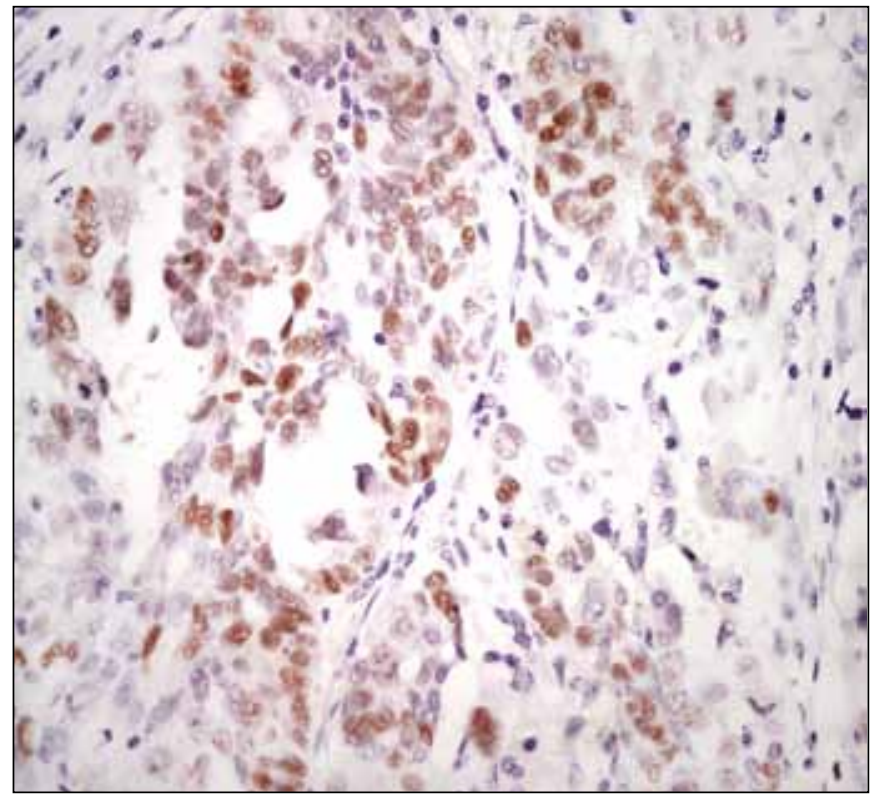

Figure 4: Immunohistochemical staining for RFP expression in ovarian serous carcinoma (x200). 


\section{DISCUSSION}

In the present study, we evaluated the expression of RFP in non-neoplastic endometrium samples as well as type I endometrial cancer in comparison to Type II endometrial cancer and found that nuclear expression of RFP was strongly correlated with serous carcinoma morphology. Due to strong positive results for serous endometrial cancer, we also included ovarian serous adenocarcinoma cases, all of which were stained strongly for RFP. This is the first report to demonstrate the differential expression RFP in 2 major subtypes of endometrial carcinoma as well as ovarian serous carcinoma.

RET finger protein, which belongs to the large B-box RING finger protein family, is widely expressed in various normal and tumor tissues, including liver, kidney, testis, breast, endometrium and germ cell tumors, namely seminomas (11-13, 15-17). There are over 200 members of the RING finger protein family reported to date, including PML, BMI1/Mel-18, RING1, and KAP-1 $(8,18,19)$.

Apart from histological and clinical features, Type I and Type II endometrial cancers are further distinguished by genetic alterations since they are associated with mutations of independent sets of genes. While Type I tumors show microsatellite instability and involve mutations in PTEN (17, 20-23), K-ras (17), and $\beta$-catenin (20), as well as defects in DNA mismatch repair $(24,25)$; Type II tumors frequently exhibit aneuploidy and p53 mutations (26-29), as well as overexpression of p16 $(29,30)$, insulin-like growth factor II messenger RNA-binding protein (31), HER-2/neu (c-ErbB2) $(32,33)$ and have alterations of E-cadherin $(34$, $35)$ and claudins (36-40).

In contrast to significant advances in the study of type I (mainly endometrioid carcinomas) endometrial carcinogenesis, studies on type II (mainly ESC) carcinogenesis have been limited. The higher case-fatality rate associated with type II cancers is probably at least in part a function of the advanced stage at which a significant proportion of patients with type II cancers present (41). Zheng et al. recently proposed a model in an effort to understand endometrial serous carcinogenesis so that its precancers can be delineated and treated, stating that endometrial serous carcinoma starts from latent precancer (p53 signature glands), develop into precancerous lesions (endometrial glandular dysplasia), then into early serous cancer (serous endometrial intraepithelial carcinoma), and finally to fully developed endometrial serous carcinoma (42).
Currently, how RFP contributes to carcinogenesis is unclear. However, RING finger proteins are thought to play roles in the formation and architecture of large protein complexes that contribute to diverse cellular processes such as oncogenesis, apoptosis, development, and ubiquitination $(8,18,19,43-45)$. We had previously reported a significant correlation between RFP staining and overexpression of ErbB2, which is a well defined poor prognostic factor for invasive breast carcinoma, both at protein and gene level (11). Townson et al. previously reported that; although RFP did not interact with estrogen receptor- $\alpha$ (ESR1) directly, that RFP is a component of an ESR1 regulatory complex (46). RFP was also shown to make complexes with histone deacetylase 1 (HDAC1) and transcription factor NF-Y (15). This protein complex is reported to confer resistance to anticancer drugs by decreasing the expression of thioredoxin binding protein-2 (TBP-2); which is an inhibitor of thioredoxin, a scavenger of reactive oxygen species (ROS); and sensitizes cells to oxidative stress and cisplatin (47-50).

Tsukamoto et al. had previously reported RFP expression as a predictive marker for an unfavorable clinical outcome in patients with endometrial cancer irrespective of histological type and proposed positive RFP expression as an independent prognostic factor for survival (15).

The mechanism by which RFP plays a role in development of serous carcinoma is yet to be investigated. Tsukamoto et al. had found that integrin $\beta 1$ and integrin $\alpha 2$ expressions were significantly decreased in RFP knockdown cells, suggesting that importance of these integrins might play a role in the progression of endometrial cancer (15). They also suggested that RFP expression might be associated with the poor clinical outcome of endometrial cancer by regulating cancer cell resistance to oxidative stress and resistance to anticancer drugs such as cisplatin (15). The role of RFP in estrogen signaling pathways might also be of importance regarding the frequent loss of expression of the estrogen and progesterone receptors in serous endometrial carcinomas $(26,51,52)$ and RFP being proposed a component of an ESR1 regulatory complex (46).

In this study, we found that RFP stains specifically the serous type endometrial carcinomas and none of endometrioid type cancers, irrespective of grade. Although the assessment of cell type is straightforward in most cases and there is a reported reproducibility of 0.62 to 0.87 , determining the cell of origin can become problematic; especially in high grade tumors (53-56). According to World Health Organization definitions, the diagnosis of primary endometrioid adenocarcinoma should be given 
where the tumor is composed of glands resembling those of the normal endometrium, generally in a background of atypical hyperplasia, whereas serous carcinoma is characterized by a complex pattern of papillae with cellular budding and not infrequently psammoma bodies, typically in an atrophic endometrium or with accompanying highgrade in situ carcinoma (endometrial intraepithelial carcinoma) (57). However, endometrioid carcinomas showing papillary growth or slit-like glandular spaces and serous carcinomas having a predominantly or exclusively glandular architecture, or areas of solid growth exist in real life $(58,59)$. This is where immunohistochemistry is being more and more frequently used as an adjuvant to H\&E diagnosis. The markers most commonly used currently in clinic are ER, PR, p53, p16, proliferation index and PTEN, with varying sensitivity and specificities (60). Approximately $70-90 \%$ of serous carcinomas express strong and diffuse nuclear p53 staining; however p53 is overexpressed in $10-35 \%$ of endometrioid carcinomas, and majority of these are the high grade ones (28, 58, 61-63). Almost all low-grade and most of high grade endometrioid carcinomas show ER and/or PR expression and pure serous carcinomas are expected typically to be negative for ER and PR. However, serous carcinomas associated with low-grade endometrioid carcinoma or atypical hyperplasia often show ER and/or PR expression (26). A high proliferation index is 'typical of serous carcinoma (mean labelling index of 50\% positive nuclei versus $20 \%$ ), although there is no real cut-off value (64). Serous carcinomas should demonstrate diffuse and strong p16 staining and endometrioid carcinomas may show patchy weak to even moderate staining with p16 regardless of grade $(30,65)$. Loss of expression PTEN is also reported to be characteristic of endometrioid carcinoma, especially of high grade endometrioid compared to serous histology (58). Currently a panel of at least 3-4 markers are needed to aid in the separation of endometrioid versus serous type, especially in cases with atypical morphological and high grade features. The strong correlation of RFP expression with serous morphology in our study not only in carcinomas of endometrium but also of ovarian origin might greatly ease this distinction as more is found out about the molecular role of RFP in serous tumor carcinogenesis.

\section{REFERENCES}

1. Stewart BW, Kleihues P: World Cancer Report. Lyon, World Health Organization, 2003

2. Doll A, Abal M, Rigau M, Monge M, Gonzalez M, Demajo S, Colas E, Llaurado M, Alazzouzi H, Planaguma J, Lohmann MA, Garcia J, Castellvi S, Ramon y Cajal J, Gil-Moreno A, Xercavins J, Alameda F, Reventos J: Novel molecular profiles of endometrial cancer-new light through old windows. J Steroid Biochem Mol Biol 2008, 108:221-229
3. Bokhman JV: Two pathogenetic types of endometrial carcinoma. Gynecol Oncol 1983, 15:10-17

4. Lax SF: Molecular genetic pathways in various types of endometrial carcinoma: from a phenotypical to a molecularbased classification. Virchows Arch 2004, 444:213-223

5. Reddy BA, Etkin LD: A unique bipartite cysteine-histidine motif defines a subfamily of potential zinc-finger proteins. Nucleic Acids Res 1991, 19:6330

6. Reddy BA, Etkin LD, Freemont PS: A novel zinc finger coiledcoil domain in a family of nuclear proteins. Trends Biochem Sci 1992, 17:344-345

7. Freemont PS: The RING finger. A novel protein sequence motif related to the zinc finger. Ann N Y Acad Sci 1993, 684:174-192

8. Saurin AJ, Borden KL, Boddy MN, Freemont PS: Does this have a familiar RING?. Trends Biochem Sci 1996, 21:208-214

9. Takahashi M, Ritz J, Cooper GM: Activation of a novel human transforming gene, ret, by DNA rearrangement. Cell 1985, 42:581-588

10. Takahashi M, Inaguma Y, Hiai H, Hirose F: Developmentally regulated expression of a human "finger"-containing gene encoded by the 5' half of the ret transforming gene. Mol Cell Biol 1988, 8:1853-1856

11. Tezel GG, Uner A, Yildiz I, Guler G, Takahashi M: RET finger protein expression in invasive breast carcinoma: relationship between RFP and ErbB2 expression. Pathol Res Pract 2009, 205:403-408

12. Tezel G, Nagasaka T, Iwahashi N, Asai N, Iwashita T, Sakata K, Takahashi M: Different nuclear/cytoplasmic distributions of RET finger protein in different cell types. Pathol Int 1999, 49: 881-886

13. Tezel G, Nagasaka T, Shimono Y, Takahashi M: Differential expression of RET finger protein in testicular germ cell tumors. Pathol Int 2002, 52:623-627

14. Zhang JM, Hashimoto M, Kawai K, Murakumo Y, Sato T, Ichihara M, Nakamura S, Takahashi M: CD109 expression in squamous cell carcinoma of the uterine cervix. Pathol Int 2005, $55: 165-169$

15. Tsukamoto H, Kato T, Enomoto A, Nakamura N, Shimono Y, Jijiwa M, Asai N, Murakumo Y, Shibata K, Kikkawa F, Takahashi M: Expression of Ret finger protein correlates with outcomes in endometrial cancer. Cancer Sci 2009, 100:1895-1901

16. Tezel G, Shimono Y, Murakumo Y, Kawai K, Fukuda T, Iwahashi N, Takahashi M: Role for O-glycosylation of RFP in the interaction with enhancer of polycomb. Biochem Biophys Res Commun 2002, 290:409-414

17. Velasco A, Bussaglia E, Pallares J, Dolcet X, Llobet D, Encinas M, Llecha N, Palacios J, Prat J, Matias-Guiu X: PIK3CA gene mutations in endometrial carcinoma: correlation with PTEN and K-RAS alterations. Hum Pathol 2006, 37:1465-1472

18. Borden KL: RING fingers and B-boxes: zinc-binding proteinprotein interaction domains. Biochem Cell Biol 1998, 76:351-358

19. Borden KL: RING domains: master builders of molecular scaffolds? J Mol Biol 2000, 295:1103-1112 
20. Konopka B, Janiec-Jankowska A, Czapczak D, Paszko Z, Bidzinski M, Olszewski W, Goluda C: Molecular genetic defects in endometrial carcinomas: microsatellite instability, PTEN and beta-catenin (CTNNB1) genes mutations. J Cancer Res Clin Oncol 2007, 133:361-371

21. Mutter GL: Pten, a protean tumor suppressor. Am J Pathol 2001, 158:1895-1898

22. Risinger JI, Hayes AK, Berchuck A, Barrett JC: PTEN/MMAC1 mutations in endometrial cancers. Cancer Res 1997, 57:47364738

23. Tashiro H, Blazes MS, Wu R, Cho KR, Bose S, Wang SI, Li J, Parsons R, Ellenson LH: Mutations in PTEN are frequent in endometrial carcinoma but rare in other common gynecological malignancies. Cancer Res 1997, 57:3935-3940

24. Esteller M, Levine R, Baylin SB, Ellenson LH, Herman JG: MLH1 promoter hypermethylation is associated with the microsatellite instability phenotype in sporadic endometrial carcinomas. Oncogene 1998, 17:2413-2417

25. Faquin WC, Fitzgerald JT, Boynton KA, Mutter GL: Intratumoral genetic heterogeneity and progression of endometrioid type endometrial adenocarcinomas. Gynecol Oncol 2000, 78:152-157

26. Lax SF, Pizer ES, Ronnett BM, Kurman RJ: Clear cell carcinoma of the endometrium is characterized by a distinctive profile of p53, Ki-67, estrogen, and progesterone receptor expression. Hum Pathol 1998, 29:551-558

27. Nordstrom B, Strang P, Lindgren A, Bergstrom R, Tribukait B: Endometrial carcinoma: the prognostic impact of papillary serous carcinoma (UPSC) in relation to nuclear grade, DNA ploidy and p53 expression. Anticancer Res 1996, 16:899-904

28. Sherman ME, Bur ME, Kurman RJ: p53 in endometrial cancer and its putative precursors: evidence for diverse pathways of tumorigenesis. Hum Pathol 1995, 26:1268-1274

29. Chiesa-Vottero AG, Malpica A, Deavers MT, Broaddus $R$, Nuovo GJ, Silva EG: Immunohistochemical overexpression of p16 and p53 in uterine serous carcinoma and ovarian high-grade serous carcinoma. Int J Gynecol Pathol 2007, 26:328-333

30. Yemelyanova A, Ji H, Shih IeM, Wang TL, Wu LS, Ronnett $B M$ : Utility of p16 expression for distinction of uterine serous carcinomas from endometrial endometrioid and endocervical adenocarcinomas: immunohistochemical analysis of 201 cases. Am J Surg Pathol 2009, 33:1504-1514

31. Zheng W, Yi X, Fadare O, Liang SX, Martel M, Schwartz PE, Jiang Z: The oncofetal protein IMP3: a novel biomarker for endometrial serous carcinoma. Am J Surg Pathol 2008, 32: 304-315

32. Santin AD, Bellone S, Gokden M, Palmieri M, Dunn D, Agha J, Roman JJ, Hutchins L, Pecorelli S, O'Brien T, Cannon MJ, Parham GP: Overexpression of HER-2/neu in uterine serous papillary cancer. Clin Cancer Res 2002, 8:1271-1279

33. Santin AD, Bellone S, Gokden M, Palmieri M, Dunn D, Agha J, Roman JJ, Hutchins L, Pecorelli S, O’Brien T, Cannon MJ, Parham GP: Racial differences in the overexpression of epidermal growth factor type II receptor (HER2/neu): a major prognostic indicator in uterine serous papillary cancer. Am J Obstet Gynecol 2005, 192:813-818
34. Holcomb K, Delatorre R, Pedemonte B, McLeod C, Anderson L, Chambers J: E-cadherin expression in endometrioid, papillary serous, and clear cell carcinoma of the endometrium. Obstet Gynecol 2002, 100:1290-1295

35. Huszar M, Pfeifer M, Schirmer U, Kiefel H, Konecny GE, BenArie A, Edler L, Munch M, Muller-Holzner E, Jerabek-Klestil S, Abdel-Azim S, Marth C, Zeimet AG, Altevogt P, Fogel M: Upregulation of L1CAM is linked to loss of hormone receptors and E-cadherin in aggressive subtypes of endometrial carcinomas. J Pathol 220:551-561

36. Santin AD, Bellone S, Marizzoni M, Palmieri M, Siegel ER, McKenney JK, Hennings L, Comper F, Bandiera E, Pecorelli S: Overexpression of claudin-3 and claudin-4 receptors in uterine serous papillary carcinoma: novel targets for a type-specific therapy using Clostridium perfringens enterotoxin (CPE). Cancer 2007, 109:1312-1322

37. Konecny GE, Agarwal R, Keeney GA, Winterhoff B, Jones MB, Mariani A, Riehle D, Neuper C, Dowdy SC, Wang HJ, Morin PJ, Podratz KC: Claudin-3 and claudin-4 expression in serous papillary, clear-cell, and endometrioid endometrial cancer. Gynecol Oncol 2008, 109:263-269

38. Hecht JL, Mutter GL: Molecular and pathologic aspects of endometrial carcinogenesis. J Clin Oncol 2006, 24:4783-4791

39. Bansal N, Yendluri V, Wenham RM: The molecular biology of endometrial cancers and the implications for pathogenesis, classification, and targeted therapies. Cancer Control 2009, 16: 8-13

40. Burton JL, Wells M: Recent advances in the histopathology and molecular pathology of carcinoma of the endometrium. Histopathology 1998, 33:297-303

41. Ueda SM, Kapp DS, Cheung MK, Shin JY, Osann K, Husain A, Teng NN, Berek JS, Chan JK: Trends in demographic and clinical characteristics in women diagnosed with corpus cancer and their potential impact on the increasing number of deaths. Am J Obstet Gynecol 2008, 198:218.e1-6

42. Zheng W, Xiang L, Fadare O, Kong B: A proposed model for endometrial serous carcinogenesis. Am J Surg Pathol 35:e1-14

43. Topcu Z, Mack DL, Hromas RA, Borden KL: The promyelocytic leukemia protein PML interacts with the proline-rich homeodomain protein PRH: a RING may link hematopoiesis and growth control. Oncogene 1999, 18:7091-7100

44. Shimono Y, Murakami H, Hasegawa Y, Takahashi M: RET finger protein is a transcriptional repressor and interacts with enhancer of polycomb that has dual transcriptional functions. J Biol Chem 2000, 275:39411-39419

45. Dho SH, Kwon KS: The Ret finger protein induces apoptosis via its RING finger-B box-coiled-coil motif. J Biol Chem 2003, 278:31902-31908

46. Townson SM, Kang K, Lee AV, Oesterreich S: Novel role of the RET finger protein in estrogen receptor-mediated transcription in MCF-7 cells. Biochem Biophys Res Commun 2006, 349: 540-548

47. Kato T, Shimono Y, Hasegawa M, Jijiwa M, Enomoto A, Asai N, Murakumo Y, Takahashi M: Characterization of the HDAC1 complex that regulates the sensitivity of cancer cells to oxidative stress. Cancer Res 2009, 69:3597-3604 
48. Nishiyama A, Matsui $M$, Iwata S, Hirota $K$, Masutani $H$, Nakamura H, Takagi Y, Sono H, Gon Y, Yodoi J: Identification of thioredoxin-binding protein-2/vitamin $\mathrm{D}(3)$ up-regulated protein 1 as a negative regulator of thioredoxin function and expression. J Biol Chem 1999, 274:21645-21650

49. Wang Y, De Keulenaer GW, Lee RT: Vitamin D(3)-up-regulated protein-1 is a stress-responsive gene that regulates cardiomyocyte viability through interaction with thioredoxin. J Biol Chem 2002, 277:26496-26500

50. Baker AF, Koh MY, Williams RR, James B, Wang H, Tate WR, Gallegos A, Von Hoff DD, Han H, Powis G: Identification of thioredoxin-interacting protein 1 as a hypoxia-inducible factor 1alpha-induced gene in pancreatic cancer. Pancreas 2008, 36: 178-186

51. Demopoulos RI, Mesia AF, Mittal K, Vamvakas E: Immunohistochemical comparison of uterine papillary serous and papillary endometrioid carcinoma: clues to pathogenesis. Int J Gynecol Pathol 1999, 18:233-237

52. Sasano H, Comerford J, Wilkinson DS, Schwartz A, Garrett CT: Serous papillary adenocarcinoma of the endometrium. Analysis of proto-oncogene amplification, flow cytometry, estrogen and progesterone receptors, and immunohistochemistry. Cancer 1990, 65:1545-1551

53. Alkushi A, Abdul-Rahman ZH, Lim P, Schulzer M, Coldman A, Kalloger SE, Miller D, Gilks CB: Description of a novel system for grading of endometrial carcinoma and comparison with existing grading systems. Am J Surg Pathol 2005, 29:295-304

54. Scholten AN, Creutzberg CL, Noordijk EM, Smit VT: Long-term outcome in endometrial carcinoma favors a two- instead of a three-tiered grading system. Int J Radiat Oncol Biol Phys 2002, 52:1067-1074

55. Kapucuoglu N, Bulbul D, Tulunay G, Temel MA: Reproducibility of grading systems for endometrial endometrioid carcinoma and their relation with pathologic prognostic parameters. Int J Gynecol Cancer 2008, 18:790-796
56. Gemer O, Uriev L, Voldarsky M, Gdalevich M, Ben-Dor D, Barak F, Anteby EY, Lavie O: The reproducibility of histological parameters employed in the novel binary grading systems of endometrial cancer. Eur J Surg Oncol 2009, 35:247-251

57. Devilee FATP: Pathology and Genetics of Tumours of the Breast and Female Genital Organs. Lyon, IARC Press, 2003

58. Darvishian F, Hummer AJ, Thaler HT, Bhargava R, Linkov I, Asher M, Soslow RA: Serous endometrial cancers that mimic endometrioid adenocarcinomas: a clinicopathologic and immunohistochemical study of a group of problematic cases. Am J Surg Pathol 2004, 28:1568-1578

59. Murray SK, Young RH, Scully RE: Uterine endometrioid carcinoma with small nonvillous papillae: An analysis of 26 cases of a favorable-prognosis tumor to be distinguished from serous carcinoma. Int J Surg Pathol 2000, 8:279-289

60. Clarke BA, Gilks CB: Endometrial carcinoma: controversies in histopathological assessment of grade and tumour cell type. J Clin Pathol 63:410-415

61. Kovalev S, Marchenko ND, Gugliotta BG, Chalas E, Chumas J, Moll UM: Loss of p53 function in uterine papillary serous carcinoma. Hum Pathol 1998, 29:613-619

62. Soslow RA, Shen PU, Chung MH, Isacson C: Distinctive p53 and $\mathrm{mdm} 2$ immunohistochemical expression profiles suggest different pathogenetic pathways in poorly differentiated endometrial carcinoma. Int J Gynecol Pathol 1998, 17:129-134

63. Tashiro H, Isacson C, Levine R, Kurman RJ, Cho KR, Hedrick L: p53 gene mutations are common in uterine serous carcinoma and occur early in their pathogenesis. Am J Pathol 1997, 150:177-185

64. Al Kushi A, Lim P, Aquino-Parsons C, Gilks CB: Markers of proliferative activity are predictors of patient outcome for lowgrade endometrioid adenocarcinoma but not papillary serous carcinoma of endometrium. Mod Pathol 2002, 15:365-371

65. Reid-Nicholson M, Iyengar P, Hummer AJ, Linkov I, Asher $M$, Soslow RA: Immunophenotypic diversity of endometrial adenocarcinomas: implications for differential diagnosis. Mod Pathol 2006, 19:1091-1100 